\title{
The Impacts of the Tests on the Scientific Process Skills of the Pre-School Children
}

\author{
Munise Duran, Merve Ünal \\ İnönü University, Malatya, Turkey
}

\begin{abstract}
The purpose of this study is to examine the impacts of the test method on the scientific process skills of the pre-school period children. The study has been conducted on 10 children in a school located within Malatya central province. The scientific process observation form has been used for gathering data. A general information form has been prepared by the researchers aiming to gather the personal data about the children and families thereof. The tests related to the scientific processes of the children have been applied a total of eight weeks as once in a week. The researchers have recorded the frequencies of the scientific process behaviours of the children during such test applications in the observation forms. The obtained data have been analysed using Statistical Package for the Social Sciences (SPSS) 17 program. The findings have shown that the applied tests have increased the scientific process using skills and scientific behaviours of the children.
\end{abstract}

Keywords: pre-school period, scientific processes, tests

\section{Introduction and Literature Review}

The pre-school education is defined as the education given by families and institutions from the birth of the child till starting to formal education as which in a great scale assists/completes the physical, psycho-motor, social-emotional-mental, and lingual development of the child, i.e., playing a decisive role in the future life of the child (Aral, Kandır, \& Yaşar, 2002). It is concrete that the pre-school education is the first step of the educational process where the child faces for the first time the information system. The child's perception is most open in the pre-school period.

In such period, the curiosity sense of the child aiming to understand the world is in the foremost plan. The features of the pre-school period require having knowledge about the complicated and interlocked processes which relate to mental, social, emotional, physical, and lingual titles; whereas, one should also know how to assist and develop such processes by means of establishing suitable educational environments. The information taken in this period will provide positive contributions to the child in future periods (Turaşl1, 2000). Thus, the pre-school education of the child has an incontrovertible significance by means of the development of the child.

Through the pre-school education, the children are supported via several activities that will ensure them to mean and reason the world they live in. Such activities aim the child to have scientific process skills, such as

Munise Duran, Ph.D., lecturer, Division of Pre-school Teaching, Department of Primary Education, Faculty of Education, İnönü University.

Merve Ünal, Ph.D., research assistant, Division of Pre-school Teaching, Department of Primary Education, Faculty of Education, İnönü University. 
active participation, observation making, comparison, classification, cause-consequence, detail detection, testing, and hypothesis formation (Ayvac1, Devecioğlu, \& Yiğit, 2002).

The little children employ a natural curiosity whereas they are in an uninterrupted attempt of researching the surrounding world. They seek information about the world whereas they continuously perform observations incidences and how the daily tools are operated. They play with the objects and wait for the results. In short, they use scientific processes and form their understanding of the world (Ünal \& Akman, 2006).

The entire scientific practices used for revealing the information and meaningfully interpreting the explorations have been named as the scientific processes (Çepni, Ayvacı, \& Bacanak, 2004; Şimşek \& Çınar, 2007). The scientific processes ensure the child to have new information through concrete tests. The scientific process skills cover then the general tools of science and all the other information and skills required for performing scientific research (Harlen, 1999; Carin \& Bass, 2001; Aktamış \& Ergin, 2007).

These skills develop being constructed one on another. The observation, comparison, classification, measuring, and communication skills, which are in use from the first years of the life, form the foundations of the scientific processes whereas these are included in the general skills that are used for running the daily life. The scientific process skills are the basic merits which ensure the children to be active, develop a positive approach towards the science, ease to understand the science, improve self-learning responsibilities, increase the lasting of learned material, and which ensure them to use the research methods and ways. The children, once they start their basic education, use the medium level conclusion and prediction process skills which include gathering and organizing the detected data at mental level. If the children employ a strong basic and medium process skills, then they may gain the superior scientific skills, such as hypothesis formation and variable detection much more easily (Charlesworth \& Lind, 2003; Tan \& Temiz, 2003; Gallenstein, 2005; Arnas, 2007).

The children use the same scientific processes likewise adults and develop ideas about the surrounding world utilizing self-performed tests (Ross, 2000). The children are defined as young scientists since they use all their sensing organs for prediction, observation, measuring, comparison, classification, communication, prediction testing, tool using, and detail detection. However, they need assistance in such processes. Indeed, the children should ask questions and perform tests, exactly as scientists, till they obtain the right conclusions (Torres \& Vitti, 2007). Under this context, permitting and assisting the children to explore the scientific processes then contributing them in their development of organizing, classifying, problem-solving, cause exploration, reasoning, and other mental skills (Eggers, 2005).

The period when the children start to use scientific process skills is known as the pre-school periods. One of the activities performed in pre-school periods is the scientific activities. Such scientific activities in pre-school period include testing methods that permit the child to see, touch, feel, perform, and experience, i.e., to which the child participates in full activeness and accordingly strengthening the development and learning experiences (Balat \& Önkol, 2014). Moreover, the tests relate to more than one sense of the child as to make the learning a lasting experience together with providing concrete incidences being used by the child in understanding the scientific concepts and scientific processes (Şahin, 2000). The tests permit the child to structure the gained information. That is, the children being able to form the information in their minds then will assist them in future years for understanding the complicated scientific concepts and employing a scientific point of view. The teacher, while conducting the tests, shall express the scientific facts as to incite the scientific steps in the child and to contribute for the thinking skills and problem-solving abilities of the same (Balat \& Önkol, 2014). 
The test performance together with children does not require a laboratory all the time. The teachers may use the simple materials of daily life when performing tests together with the pre-school period children. That requires the teacher to establish certain environments but which flash the curiosity and interest senses of the child. Test making with simple materials is a teaching method through which the child truly interacts with the objects in real life environments (Flick, 1993).

The scientific process skills permit the children to reach new information through concrete experiences. These processes and skills develop the thinking strength of the child while solving a problem and generate a curiosity in the child about how to reach for such solution. These skills may be developed in the children through scientific education by means of experiences obtained from tests using simple materials. These simple tests are important since they made the child able to learn by testing and structure the information much more easily. As in line with active learning approach, the children may develop such processes by making the tests themselves or directly by interpreting their own observations themselves (Harlen \& Qualter, 2009). The tests conducted with simple materials help the children to build up a cause-consequence relation by means of observing the steps of their own-conducted tests instead of memorizing process (Haury \& Rillero, 1994).

\section{Method and Procedure}

The purpose of this study is to examine the impacts of the test method on the scientific process skills of the pre-school period children.

The pattern of the study is single group pre-test/final test model. This pattern is used for explaining the impacts of the new education methods or for, from time to time, causing attraction to certain new education styles through declaring the dependent variable measurements by the researchers (Cohen, Manion, \& Morrison, 2007). The study is conducted on 10 students of a provincial school in Malatya. The school is not sufficiently equipped by means of physical education tool and the students are from low socio-economic classes. The tests to be used by the children for scientific processes are conducted once in each week and such practice is totalled to eight weeks. The researchers have recorded the frequencies of the scientific process behaviours of the children during such test applications in the observation forms. The obtained data have been analysed using Statistical Package for the Social Sciences (SPSS) 17 program.

\section{Data Gathering Tools}

The scientific process observation form, which has been developed by Lind (2000) and adapted to Turkish by Akman, Üstün, and Güler (2003), has been used for gathering data. The observation form consists of two sub-sections. The first section is the scientific processes recording form. This form includes five categories as observing, classifying, communication, measuring, and predicting. The second section is scientific behaviours assessment form. This section includes the categories of curious, collaborating, ignorant, open-minded, and safe material using. These categories are assessed by the researchers before the test and after the test. Moreover, the researchers have also generated another form which includes the demographic data about the participating children.

\section{Determination of the Working Group}

In the first place, we aimed to select a school of a low socio-economic level. The children in such school had never faced test method or not known the test method at all. The impacts of the test method on such children could be measured more clearly and that was the rationale to select such a school for the study. 


\section{The General Information Form}

The general information form was prepared by the researchers as aiming to gather personal data about the children and their families. This form included the name, surname, age, gender of the child as well as if it has obtained pre-school education or not, number of brothers and sisters, age of the mother and father, education level of the parents, and profession of the parents. The general information forms are completed by the parents of the children. According to the data seen in the general information forms, the demographic characteristics of the participating children are given in Table 1.

Table 1

Demographic Features of the Participating Children

\begin{tabular}{|c|c|c|}
\hline \multicolumn{3}{|c|}{ Gender } \\
\hline Girl & 6 & \\
\hline Boy & 4 & \\
\hline \multicolumn{3}{|c|}{ Age } \\
\hline $48-60$ months & \multicolumn{2}{|l|}{4} \\
\hline 60-72 months & \multicolumn{2}{|l|}{6} \\
\hline \multicolumn{3}{|c|}{ Number of siblings } \\
\hline Single child & \multicolumn{2}{|l|}{3} \\
\hline Two siblings & \multicolumn{2}{|l|}{2} \\
\hline 3 and more & \multicolumn{2}{|l|}{5} \\
\hline \multicolumn{3}{|c|}{ Pre-school education } \\
\hline Yes & \multicolumn{2}{|l|}{-} \\
\hline \multirow[t]{2}{*}{ No } & \multicolumn{2}{|l|}{10} \\
\hline & Age of mother & Age of father \\
\hline 29 years or younger & 3 & 2 \\
\hline $30-39$ years old & 6 & 2 \\
\hline \multirow[t]{2}{*}{40 years old and older } & 1 & 6 \\
\hline & Education level of mother & Education level of father \\
\hline Illiterate & 2 & - \\
\hline Primary school & 8 & 9 \\
\hline Secondary school & - & - \\
\hline High school & - & 1 \\
\hline \multirow[t]{2}{*}{ University } & - & - \\
\hline & Mother's profession & Father's profession \\
\hline Housewife & 10 & - \\
\hline Officer & - & 1 \\
\hline Worker & - & - \\
\hline Self-employed & - & 9 \\
\hline
\end{tabular}

According to the aforementioned in Table 1, six of the children are girls and remaining four are boys. None of the children have been provided pre-school period education before. Forty percent of the children are six years old and $60 \%$ are five years old. Fifty percent of the participants are two siblings whereas the other $50 \%$ have two or more brothers/sisters. The mothers are generally between 30 to 39 years old whereas their fathers are older than 40 years old. Two mothers are illiterate whereas eight mothers are primary school graduate. Only one father is a high school graduate whereas $90 \%$ of the fathers are primary school graduates. All the mothers are housewives and do not work. Only one father is a retired state officer. The other fathers are self-employed. 


\section{Test Education Program}

The tests have been prepared for the 36 to 72 months children as in line with the pre-school education program objectives and gains; whereas, considering the individual differences of the children and developmental features thereof as well as depending on the principles of from familiar to distant knowledge, from simple to complicated, and from concrete to abstract. The activities included in the Test Education Program include tests that, generally, let the children use their scientific process skills and assist them in independent thinking, decision-making, and problem-solving. The tests support the children in more concrete observation of the phenomenon, however, also are planned to ensure the children to learn via experimenting, establish cause-consequence relations and accordingly learn more lasting and meaningfully. The tests are designed as to let the children express their ideas whereas to test them and discuss the rising results. The children are enabled to interact with the test and discuss the test results afterwards. By asking open-ended questions after the test, the children are required to outline the test and the respective assessments are performed by making use of test-related data sheets.

There are eight tests each to be conducted once in a single week. While preparing the tests, the self-life experiences of the children are based on (i.e., as in line with the interests and needs of the children) whereas it is aimed that the test concentrates on the self-performance and basic scientific process skills. Thus, the scientific stage of the children could be understood, their thinking skills could be developed, and their logical structure could be enabled to strengthen together with encouragement since the children would be permitted to solve test-related problems (Balat \& Önkol, 2014). The tests are prepared as considering the objectives and the general structure of the education. They have been designed as to attract the attention of the children. Before conducting the tests, games, Turkish language, music activities etc., attractions are performed as to attract the children in the environment. After the completion of the tests, test data sheets, open-ended questions (as to let them express their ideas freely) and art activities are provided as aiming to easily obtain the thoughts of the children about the tests.

\section{Findings}

When considered Table 2, the pre-test scores demonstrate a normal distribution $(p>0.05)$ whereas the final test scores deviate from normal $(p<0.05)$. Thus, we have performed non-parametric Wilcoxon (for dependent groups) test as to understand the difference between the pre-test and post-test scores.

Table 2

Scientific Processes Scores Distribution

\begin{tabular}{llll}
\hline & \multicolumn{3}{c}{ Shapiro-Wilk } \\
\cline { 2 - 4 } & Statistic & $D f$ & Sig. \\
\hline Total pre-test & 0.912 & 10 & 0.296 \\
Total final test & 0.843 & 10 & $0.048^{*}$ \\
\hline
\end{tabular}

Note. ${ }^{*} p<0.05$.

When looked at Table 3, the pre-test and post test scientific process scores of the participating children demonstrate a significant difference $(z: 2.82, p<0.05)$. The series average and total of the difference scores show that such difference is to the favour of the final test. According to such findings, the tests may be claimed to affect positively the scientific processes of the pre-school children. 
Table 3

Wilcoxon Marked Series Test Results for Pre-Test and Post-Test Scientific Process Scores

\begin{tabular}{lrlcll}
\hline Final test-pre-test & $N$ & Series average & Series total & $z$ & $p$ \\
\hline Negative series & 0 & 0 & 0 & $2.82^{*}$ & $0.005^{*}$ \\
Positive series & 10 & 5.50 & 55 & & \\
Equal & 0 & & & & \\
\hline
\end{tabular}

Note. ${ }^{*} p<0.05$.

When considered the Table 4, the pre-test scores demonstrate a normal distribution $(p>0.05)$ whereas the final test scores deviate from normal $(p<0.05)$. Thus, we have performed non-parametric Wilcoxon (for dependent groups) test as to understand the difference between the pre-test and post-test scientific behaviour scores.

Table 4

Scientific Behaviours Scores Distribution

\begin{tabular}{llll}
\hline & \multicolumn{3}{c}{ Shapiro-Wilk } \\
\cline { 2 - 4 } & Statistic & $D f$ & Sig. \\
\hline Total pre-test & 0.956 & 10 & 0.741 \\
Total final test & 0.794 & 10 & $0.012 *$ \\
\hline
\end{tabular}

Note. ${ }^{*} p<0.05$.

When looked at the Table 5, the pre-test and post-test scientific behaviour scores of the participating children demonstrate a significant difference $(z: 2.82, p<0.05)$. The series average and total of the difference scores show that such difference is to the favour of the final test. According to such findings, the tests may be claimed to affect positively the scientific processes of the pre-school children.

Table 5

Wilcoxon Marked Series Test Results for Pre-Test and Post-Test Scientific Behaviour Scores

\begin{tabular}{lrlcll}
\hline Final test-pre-test & $N$ & Series average & Series total & $z$ & $p$ \\
\hline Negative series & 0 & 0 & 0 & $2.82^{*}$ & $0.005^{*}$ \\
Positive series & 10 & 5.50 & 55 & & \\
Equal & 0 & & & & \\
\hline
\end{tabular}

Note. ${ }^{*} p<0.05$.

\section{Discussion, Conclusion, and Recommendations}

This study has been performed in a school under the charge of Ministry of National Education with pre-school aged children. The findings and observations of the study have shown that the children are curious with increased interest and desire towards the tests. The researchers have seen that the children participate in the tests more actively and enjoy tests through time. Similarly, the works of Turpin and Cage (2004), Ornstein (2006), Önen and Gürdal (2006), Büyüktaşkapu, Çeliköz, and Akman (2012) have conducted education programs in which the children are included in a test and perform personal practices whereas they have also conclude that the scientific process skills of the children are developed through such research/test activities (Ünal \& Aral, 2014) and that they could make plans and practices suiting the faced problems, i.e., generating solutions and establishing cause-consequence relations. Moreover, Zacharia, Loizou, and Papaevripidou (2012) 
have examined the significance of touching sense through educational tests. The results of such study show that the tests performed by touching the materials are more effective whereas the children act more curious and in a questioning manner as well as with increased prediction and observation skills. Thus, the teachers should let the children to perform the tests themselves and manage the testing procedure.

We have reached the following conclusions from this study:

1. The tests have increased the scientific process using skills of the children;

2. The tests have caused an increase in scientific behaviours of the children;

3. The teachers should plan activities that attract the curiosity and interests of the children as to develop the scientific process skills of the pre-school period children.

The pre-school child is within the pre-operational stage among the cognitive development stages of Piaget. In such period, the child hears and feels the observed events. The abstract concepts then should be transformed to be sensed by more sensing organs, i.e., should be made concretely understandable by the child. The tests help the children to learn by means of serving concrete experiences and reanimation of such concrete events in the mind. Piaget claims that the formed unbalances cause new schemes in human mind; that is to say, new learning processes (Senemoğlu, 2010). Thus, the teachers should cause complicated instances in such period for the children and ensure them to experience unbalanced situations which, in turn, will force the child to form new schemes and new learning stages. But the teacher should generate such complicated situations neither too below the level of the child and nor too high. The situation of complexity should be planned in a level which will be perceived by the child as well as attract the child. Such situations may be designed as with tests including simple materials in line with the development levels of the child and as connected to real life. Thus, the tests that do not require high economic sources may be performed using simple daily life materials. Under this context, the tests prepared with simple materials are inexpensive; however, employ high values by means of learning to be experienced by the child. At the same time, the tests to be conducted with simple machines are also suit with the philosophy of the structuring approach. The structuring approach foresees that the child should structure the information in its own mind (Gelman \& Brenneman, 2004). This approach is based on the ideas of Piaget and Vygotsky and employs a program (Pre-school Pathways to Science). This program has proved that the four to five years old children may be provided observation, prediction, prediction control, observation recording skills, and has shown that such children could gain scientific thinking skills likewise and in the same complexity with adult scientists and researchers.

Our study has shown that the scientific behaviours of the students have also improved through the tests they have conducted throughout the research. The students have become more curious, in collaboration with friends and have used the test materials in a safe manner. The diversity of the materials used in education has inevitably increased the motivation and interest of the students towards the activities. The use of tests for superior mental processes (like analysis performance) and correct selection of materials then will help the teachers in efficient use of time. Moreover, the teachers should also perform complementing activities (besides tests) aiming to increase the scientific process skills. For instance, story telling, dramatizing, etc. should complete the tests and strengthen the same. A study performed by Ferreira (2004) assisted this claim. Such study included certain stories related to the scientific titles aiming to increase the classifying and observing skills and related activities are performed in the class. It is seen that the children learn easier by this way whereas increased their skills of classifying and predicting. 
The teacher should start from simple tests to more complicated tests. The children should be encouraged to perform the experiment (test) and attractive tests should be selected. In situations when the test is failed, the teacher should repeat the test and successful results should be then shown (Özbek, 2009).

Korwin and Jones (1990), Wang (1994), Tsai (1999), Çeken (2002), and Laçin (2003) have performed studies and claimed that the test is an active teaching method enabling a lasting learning since ensures learning by experience, uses daily materials, assists the children to understand scientific concepts, establishes and understanding towards the source of scientific information and scientific processes and acts significantly for the scientific concepts to be permanently understood.

Again other studies have proven that the scientific process skills formed through scientific programs have given the opportunity for the children as turning the information to a problem and solving then the same, instead of just memorizing the information (Rehorek, 2004).

\section{References}

Akman, B., Üstün, E., \& Güler, T. (2003). 6 yaş çocuklarının bilim süreçlerini kullanma yetenekleri (Scientific process using skills by 6 years old children). Hacettepe University, Education Faculty Periodical, 24, 11-14.

Aktamış, H., \& Ergin, Ö. (2007). Bilimsel süreç becerileri ile bilimsel yaratıcılık arasındaki ilişkinin belirlenmesi (Relation between the scientific process skills and scientific creativity). Hacettepe University, Education Faculty Periodical, 33, 11-23.

Arnas, A. Y. (2007). Okul öncesi dönemde fen eğitimi (Science education in pre-school period) (p. 146). Ankara: Kök Publishing House.

Aral, N., Kandır, A., \& Yaşar, M. C. (2002). Okulöncesi eğitim ve okulöncesi eğitim programı (Pre-school education and pre-school education program) (p. 184). İstanbul: Ya-pa Publishing House.

Ayvac1, H., Devecioğlu, Y., \& Yiğit, N. (2002). Okulöncesi öğretmenlerinin fen ve doğa etkinliklerindeki yeterliliklerinin belirlenmesi (The position of pre-school teacher for science titles and nature activities). In V. National Science and Mathematics Education Congress, Ankara, Turkey.

Balat, U. G., \& Önkol, L. F. (2014). Okul öncesi dönemde fen eğitimi (Pre-school science education) (Print). Ankara: Pegem Academy.

Büyüktaşkapu, S., Çeliköz, N., \& Akman, B. (2012). Yapılandırmacı bilim eğitimi programı'nın 6 yaş çocuklarının bilimsel süreç becerilerine etkisi (The impact of structuring science education program on scientific process skills of 6 years old children). Periodical of Education and Science (Eğitim ve Bilim Dergisi), 37(165), 275-292.

Carin, A. A., \& Bass, J. E. (2001). Teaching science as inquiry (p. 657). New Jersey: Prentice Hall.

Charlesworth, R., \& Lind, K. K. (2003). Math and science for young children (4th ed., p. 644). Clifton Park, N.Y.: Delmar/ITP.

Cohen, L., Manion, L., \& Morrison, K. (2007). Research methods in education (6th ed.). New York, N.Y.: Routledge, Taylor, \& Francis Group.

Çeken, R. (2002). Yedinci sınıf öğrencilerine basınç kavramının öğretilmesinde aktivitelerin etkisinin araştırılması (Research on the impacts of activities when teaching the concept of pressure for seventh grade students) (p. 125) (Master thesis, Gazi University, Education Sciences Institute, Ankara, Turkey).

Çepni, S., Ayvacı, H. Ş., \& Bacanak, A. (2004). Fen eğitimine yeni bir bakış: Fen-teknoloji-toplum (A new look to science education: Science-technology-society) (p. 234). Trabzon: Top-Kar Publishing House.

Eggers, T. (2005). Hands-on science for young children. Retrieved August 13, 2005, from http://www.earlychildhood.com

Ferreira, L. B. M. (2004). The role of a science story, activities, and dialogue modeled on philosophy for children in teaching basic science process skills to fifth graders (Unpublished Ph.D. thesis, University of Montelair State).

Flick, B. L. (1993). The meanings of hands-on science. Journal of Science Teacher Education, 4(1), 1-8.

Gallenstein, N. (2005). Engaging young children in science and mathematics. Journal of Elementary Science Education, 17(2), $27-41$.

Gelman, R., \& Brenneman, K. (2004). Science learning pathways for young children. Early Childhood Research Quarterly, 19(1) $150-158$.

Harlen, W. (1999). Purposes and procedures for assessing science process skills. Assesment in Education: Principles, Policy and Practice, 6(1), 129-145. 
Harlen, W., \& Qualter, A. (2009). The teaching of science in primary schools (5th ed., p. 352). London, UK: David Fulton Publishers.

Haury, D. L., \& Rillero, P. (1994). Perspectives of hands-on science teaching. Retrieved August 12, 2013, from $\mathrm{http} / /$ www.ncrel.org/sdrs/areas/issues/content/cntareas/science/eric/eric-toc. htm

Kefi, S. (2012, April 26-28). Okul öncesi eğitimde fen deneyleri uygulanırken, temel bilimsel süreç becerilerinin, oyun yöntemi ile kazandırılmasını amaçlayan örnek bir model (A model for providing the basic scientific process skills with game method through scientific tests conducted in pre-school education) (pp. 699-714). In III. International Conference on New Trends in Education and Their Implications, Antalya, Pegem Academy Publishing House, Ankara.

Korwin, A. R., \& Jones, R. E. (1990). Do hands-on, technology-based activities enhance learning by reinforcing cognitive knowledge and retention? Journal of Technology Education, 1(2), 26-33.

Laçin, C. (2003). İlköğretim fen bilgisi öğretiminde ev laboratuvarı yönteminin kullanılması (Home laboratory method in primary school science teaching) (p. 173) (Master thesis, Gazi University, Education Sciences Institute, Ankara).

Lind, K. K. (2000). Exploring science in early childhood education (p. 358). Albany, USA: Delmar publisher.

Ornstein, A. (2006). The frequency of hands-on experimentation and student attitudes toward science: A statistically significant relation (2005-51-Ornstein). Journal of Science Education and Technology, 15(3), 285-297.

Önen, F., \& Gürdal, A. (2006). Fen deneylerinin okul öncesi ve ilköğretim 1. kademe öğrencileriyle yaratıcı düşünmeye yönelik uygulanması (Science tests as tools for canalizing the primary school first grade students and pre-school students to the creative thinking) (Declaration Book-1, pp. 186-199). In 1st International Pre-School Education Congress, Marmara University, Education Faculty, 30 June-3 July 2004, Ya-pa Publishing House, İstanbul.

Özbek, S. (2009). Okulöncesi öğretmenlerinin fen eğitimine ilişkin görüşleri ve uygulamalarının incelenmesi (The examination on the opinions and practices of the pre-school teachers for science education) (Master thesis, Çukurova University, Social Sciences Institute, Pre-School Branch, Adana).

Rehorek, J. S. (2004). Inquiry-based teaching: An example of descriptive science in action. American Biology Teacher, 66(7), 493-500.

Ross, M. E. (2000). Science their way. Young Children, 55(2), 6-13.

Senemoğlu, N. (2010). Gelişim, ögrenme ve öğretim kuramdan uygulamaya (16. Bask1) (Development, learning and teaching. from theory to practice). Ankara: Pegem Academy.

Şahin, F. (2000). Okul öncesinde fen bilgisi ögrretimi ve aktivite örnekleri (Pre-school science teaching and activities) (p. 144). İstanbul: Ya-pa Publishing House.

Şimşek, N., \& Çınar, Y. (2007). Fen ve teknoloji laboratuarı ve uygulamaları (Science and technology labs and practices) (p. 230). Ankara: Nobel Publishing House.

Tan, M., \& Temiz, B. K. (2003). Fen öğretiminde bilimsel süreç becerilerinin yeri ve önemi (The place and significance of scientific process skills in science teaching). Pamukkale University, Education Faculty Periodical, 1(13), 89-101.

Tsai, C. C. (1999). Laboratory exercises help me memorize the scientific truths': A study of eighth graders' scientific epistemological views and learning in laboratory activities. Science Education, 83(6), 654-674.

Torres, A., \& Vitti, D. (2007). A kinder science fair. Science and Children, 45, 21-25.

Turpin, T., \& Cage, B. N. (2004). The effects of an integrated activity-based science curriculum on student achievement, science process skills and science attitudes. Electronic Journal of Literacy Through Science, 3, 1-15.

Turaşlı, K. N. (2000). Okul öncesi öğretmenlerinin kiisel yeterliliklerinin eğitimde kalite kapsamında incelenmesi (Examining the personal competency of pre-school teachers with impacts to the education quality) (Unpublished master thesis, Marmara University, Educational Sciences Institute, İstanbul).

Ünal, M., \& Akman, B. (2006). Okulöncesi öğretmenlerinin fen eğitimine karsı tutumları (The attitudes of the pre-school teachers towards the science education). Hacettep University, Periodical of Education Faculty, 30, 251-257.

Ünal, M., \& Aral, N. (2014). An investigation on the effects of experiment based education program on six years olds' problem solving skills. Education and Science, 39(176), 279-291.

Wang, D. (1994). A working laboratory [Abstract]. The Science Teacher, 61(2), 26-29.

Zacharia, Z. C., Loizou, E., \& Papaevripidou, M. (2012). Is physicality an important aspect of learning through science experimentation among kindergarten students? Early Childhood Research Quarterly, 27, 447-457. 